\title{
Technè
}

La science au service de l'histoire de l'art et de la

préservation des biens culturels

48 | 2019

Les couleurs de l'Antique

\section{Considerations on the polychromy of a group of nenfro sculptures from Tuscania (Viterbo) kept in the National Archaeological Museum of Florence}

Considérations sur la polychromie d'un ensemble de sculptures en nenfro provenant de Tuscania (Viterbe) conservées au musée archéologique national de Florence

Claudia Noferi, Susanna Bracci, Giovanni Bartolozzi, Roberta lannaccone, Sara Lenzi and Donata Magrini

\section{OpenEdition}

\section{Journals}

Electronic version

URL: https://journals.openedition.org/techne/2378

DOI: 10.4000/techne.2378

ISSN: 2534-5168

\section{Publisher}

C2RMF

Printed version

Date of publication: 31 December 2019

Number of pages: 83-89

ISBN: 978-2-11-152831-4

ISSN: 1254-7867

\section{Electronic reference}

Claudia Noferi, Susanna Bracci, Giovanni Bartolozzi, Roberta Iannaccone, Sara Lenzi and Donata Magrini, "Considerations on the polychromy of a group of nenfro sculptures from Tuscania (Viterbo) kept in the National Archaeological Museum of Florence", Technè [Online], 48 | 2019, Online since 01 July 2021, connection on 02 April 2022. URL: http://journals.openedition.org/techne/2378 ; DOI: https://doi.org/10.4000/techne.2378

La revue Technè. La science au service de l'histoire de l'art et de la préservation des biens culturels est mise à disposition selon les termes de la Licence Creative Commons Attribution - Pas d'Utilisation Commerciale - Pas de Modification 4.0 International. 
Claudia Noferi

Susanna Bracci Giovanni Bartolozzi

Roberta Iannaccone

Sara Lenzi

Donata Magrini

\section{Considerations on the polychromy of a group of nenfro sculptures from Tuscania (Viterbo) kept in the National Archaeological Museum of Florence}

Considérations sur la polychromie d'un ensemble de sculptures en nenfro provenant de Tuscania (Viterbe) conservées au musée archéologique national de Florence

\begin{abstract}
The paper deals with a group of Etruscan nenfro sculptures found in Tuscania (Viterbo) and kept in the Archaeological Museum of Florence, where some of them were already displayed at the end of the 19th and early 20th century. After the flood of Florence in 1966, the Museum was heavily damaged, causing the dismemberment of many contexts, including those from Tuscania. The artefacts were then cleaned, restored and most of them were moved into the depository of the Museum and to the Villa Corsini, where they are currently kept. The sculptures were analysed by means of a totally non-invasive analytical protocol through imaging and single spot analysis. Traces mostly of yellow and red iron-based pigments for the skin tone as well as few traces of Egyptian blue were evidenced. The comparison of the obtained analytical results joined with the archaeological studies has provided new information about the sculptures, their conservation state and artistic technique as well as deepened the knowledge about their original contexts.

Keywords. Etruscan Hellenistic funerary sculpture, Tuscania, polychromy, nenfro stone, sarcophagi, non-invasive analysis, XRF (X-ray fluorescence spectroscopy), FORS (Fiber optic reflectance spectroscopy), imaging techniques.
\end{abstract}

Résumé. Cette étude porte sur un ensemble de sculptures étrusques en nenfro mises au jour à Tuscania (Viterbe) et conservées au musée archéologique national de Florence, où quelques-unes d'entre elles étaient déjà exposées à la fin du XIX siècle et au début $d u X X^{e}$. Après l'inondation de Florence en 1966, le musée a subi de lourds dégâts, entraînant la dislocation de plusieurs unités contextuelles, dont celles de Tuscania. Après nettoyage et restauration, une grande partie des æeuvres a pu être transférée au dépôt du musée et à la villa Corsini, où elles se trouvent actuellement. Les sculptures ont été étudiées selon un protocole totalement non-invasif d'imagerie scientifique et d'analyses ponctuelles. On a pu de la sorte mettre en évidence des traces de pigments, principalement jaune et rouge à base de fer, avec parfois un peu de bleu égyptien. Les résultats de ces analyses, couplés aux études archéologiques, jettent un nouvel éclairage sur les sculptures, leur état de conservation et leur technique artistique, mais aussi sur leur contexte d'origine.

Mots-clés. Sculpture funéraire étrusque hellénistique, Tuscania, polychromie, nenfro, sarcophages, analyse non-invasive, XRF (analyse par fluorescence X), FORS (Spectrométrie par réflexion à l'aide de fibre optique), imagerie.

\section{Introduction}

Polychromy on Etruscan Hellenistic funerary sculpture has not yet been studied in depth. Previous analytical campaigns on some sarcophagi dealing with gens Statlane's tombs were part of a collaboration between the National Archaeological Museum of Florence and the Institute for the Conservation and Promotion of Cultural Heritage - ICVBC-CNR, and the results were presented at the 7 th International Round Table on Polychromy in Ancient Sculpture and Architecture, held in Florence in $2015^{1}$.
At the end of the 19th and early 20th century, Luigi Adriano Milani, director of the Royal Archaeological Museum of Florence, started an acquisition program aimed to increase the Topographical Museum of Etruria's collection. During this period, the director met Giuseppe Cerasa, Honorary Inspector of Monuments and Excavations for "Toscanella" (modern Tuscania), Arlena and Cellere. Cerasa allowed the acquisition of several groups of artefacts coming from the Tuscania area (pottery, bronze and glass objects, stone and terracotta sculptures and sarcophagi). At the beginning, the objects were partly shown - in the Tuscanienses-Ferentani Museum room and in the Garden of the Museum - and partly

Claudia Noferi, Official Archeologist, Museo Archeologico Nazionale di Firenze-Direzione Regionale Musei della Toscana (claudia. noferi@beniculturali.it). Susanna Bracci, Senior Researcher, Institute for the Conservation and Promotion of Cultural Heritage ICVBC-CNR, Firenze (bracci@icvbc.cnr.it). Giovanni Bartolozzi, Researcher, Institute for Applied Physics "Nello Carrara" - IFAC-CNR, Firenze (g.bartolozzi@ifac.cnr.it). Roberta Iannaccone, Researcher, Institute for the Conservation and Promotion of Cultural Heritage ICVBC-CNR (robertaiannaccone@hotmail.com). Sara Lenzi, Independent Researcher (sara.lenzi2014@gmail.com). Donata Magrini, Researcher, Institute for the Conservation and Promotion of Cultural Heritage - ICVBC-CNR, Firenze (donata.magrini@cnr.it). 


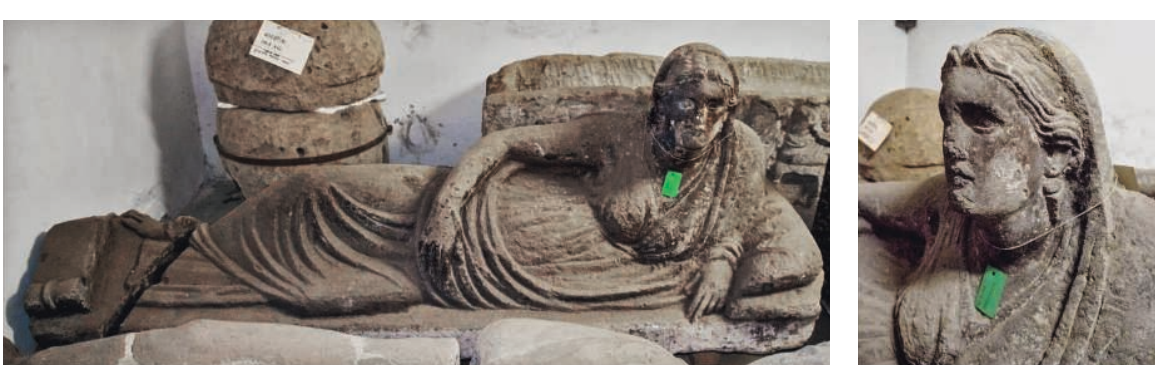

Fig. 1. Sarcophagus with female anthropomorphic lid, from Tuscania, Rosavecchia necropolis, Tomb I gens Statlane, first half of 3rd century B.C, nenfro stone $(216$ x 53 x $75 \mathrm{~cm})$, Villa Corsini a Castello (inv. 84275). (C) ICVBC-CNR.

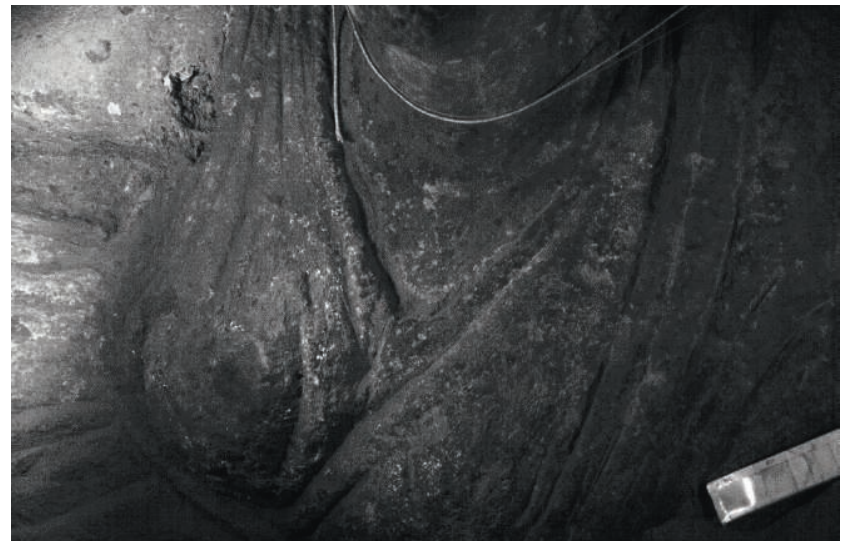

Fig. 2. VIL image. Detail of the chest of the female anthropomorphic lid (inv. 84275). (C) ICVBC-CNR.

stored. On November 4th 1966, a flood heavily damaged the museum and its contexts, causing the dismemberment of many collections, including those from Tuscania. The artefacts, after the disaster, were intensively cleaned, restored and most of them were moved into the depository of the Museum and to the Villa Corsini (Sesto Fiorentino), where they are currently kept in the courtyard and warehouse.

The present study started from this point, searching for information about the objects and their original context. After gathering archival sources concerning the sculptures and grave goods kept in the Museum and tombs, it was possible to establish an inventory of the archaeological finds purchased by the Museum and to rebuild the history of their various contexts.

\section{The sculptures and their scientific study}

The analyses on the statues were carried out in the Villa Corsini's courtyard through totally non-invasive portable techniques. The analytical protocol has already been presented in previous works ${ }^{2}$. A first preliminary screening was performed by multispectral photographic techniques, such as ultraviolet fluorescence (UVf), visible (VIS) and visible-induced luminescence (VIL) photography.

According to the preliminary results of multispectral imaging, single spot areas were selected on the objects and analysed by means of portable X-ray fluorescence spectroscopy
$(\mathrm{XRF})^{3}$ and Fibre optic reflectance spectroscopy (FORS) ${ }^{4}$. All the spots were documented through a portable optical microscope (see Experimental Appendix for further detail).

The sculptures came from four different Hellenistic hypogeal graves, all located out of the modern town of Tuscania, in the heart of the "Southern-inner Etruria". The objects reflect habits and funerary customs of the Etruscan Aristocracy, which during the Hellenistic period developed strength and cohesion, basing their power mostly on land ownership.

Two sculptures from gens Statlane's tombs, published in $2012^{5}$, were from the Rosavecchia necropolis (the current location being the "Polledrara Bassetta"), in the west side of the city, about 200 meters from the road that links Tuscania with Tarquinia. The structure was discovered in 1898 and excavated, as were many others, by G. Cerasa, who usually updated Milani by written correspondence. The hypogeum, carved in local tuff rock, is composed of two rooms. Inside, 41 sarcophagi were found: 32 (maybe 33 ) made of nenfro stone with anthropomorphic or architectural lid types, and 9 made of terracotta. Some of the sarcophagi reached Florence in 1908, with a few grave goods, five column cippi and a fragmentary lion carved in nenfro stone. All the finds from both tombs seem to cover a time span from between the end of the 4 th and the 1st century B.C. ${ }^{6}$

Concerning the polychromy analysis, five nenfro sarcophagi from gens Statlane's tombs had been chosen for the first campaign ${ }^{7}$, all with anthropomorphic lids, four of them with decorated cases in relief.

This paper introduces two more objects coming from these tombs: a sarcophagus from tomb I, with a female anthropomorphic lid and simple case, signed by Cerasa with an $\mathrm{F}$, and the fragmentary lion with part of its base, placed in the dromos of tomb I.

\section{Female sarcophagus and fragmentary lion statue}

The female anthropomorphic lid (fig. 1), dating back to the second quarter of the 3rd century B.C., shows a particular attention to details.

The excavation journal records the clear presence of a yellow colour on the earrings, consisting of a sphere and a triangle ${ }^{8}$. This sarcophagus, more or less coeval with that from gens Vipinana's tomb, which will be presented next, could be considered as a local production. Both the objects are part of Herbig's "Fassadentypus". It was mostly decorated on the front, while the back was less worked or left plain, since it was placed against one wall of the tomb ${ }^{9}$. Our objects have anthropomorphic lids shaped in a banqueting pose and are of a fine workmanship, typical of the first production of the class with 
recumbent position figures, dated to the central decades of the 3rd century B.C.

On the lid, UV fluorescence images were acquired, focusing on the upper part of the torso. It is only on the face that fluorescent areas are visible, but these are not associated with pigments. This aspect is still under study. The VIL images highlighted the presence of tiny traces of Egyptian blue on the chest (fig. 2).

FORS and XRF measurements performed on the sarcophagus showed the presence of an iron based pigment such as red ochre for the flesh tone. Otherwise, no signals linked to the presence of yellow ochre on the earrings allowed to confirm the information reported by Cerasa in the excavation journal.

The lion (fig. 3 a) probably dates back to the end of the 4th century B.C. when the tomb was created. It is comparable with a series of sepulchral lions of local production collected and studied by A. Emiliozzi ${ }^{10}$. They were interpreted as funerary guards of great family tombs, as for the most famous one, the monumental lion from Val Vidone, shown in the Florence Museum, that probably will be one of the next subjects for future analysis ${ }^{11}$.

As concerns the lion, we have information about the original polychromy thanks to Cerasa's excavation journal, recording at the time of discovery the clear presence of a "rosso minio" (red lead) on original carved surfaces both in the area of the broken snout and eyes (fig. $3 \mathrm{~b})^{12}$.

Iron based pigments were found indeed on the lion. Here, spot analyses highlighted the presence of two different iron based pigments: a red one, consisting of a mixture of iron oxides, and a yellow one obtained with iron hydroxides. In figure 3, two images acquired by the portable microscope are compared. The image on figure $3 \mathrm{c}$ shows the area on the lion's mane, while the image on figure $3 \mathrm{~d}$ shows the inner part of the eye. This evidence allowed to exclude the use of red lead as reported in the excavation journal ${ }^{13}$.

\section{Gens Vipinana's tomb: sarcophagus of a young boy}

The nenfro sarcophagus of a young boy from Vipinana's tomb (fig. 4), with cupids in relief on the case, dates back to the first half of the 3rd century B.C.
It was found in the Carcarello necropolis, south-west of the modern town of Tuscania, inside an hypogeal tomb together with 27 sarcophagi, some sculptures, many inscriptions and vessels ${ }^{14}$. The funerary complex, studied and published by G. Colonna in 1978, was attributed to gens Vipinana thanks to the presence of several inscriptions. The structure, dating between the end of the 4th and the first half of the 2nd century B.C., used for a short period during the Julio-Claudian dynasty, was excavated in 1839 by the Campanari, a family of antique dealers, and it was rebuilt in their house garden inside the historical centre of Tuscania. The sarcophagus of a young boy was purchased by the Museum in 1894 after the dispersion of the Campanari collection.

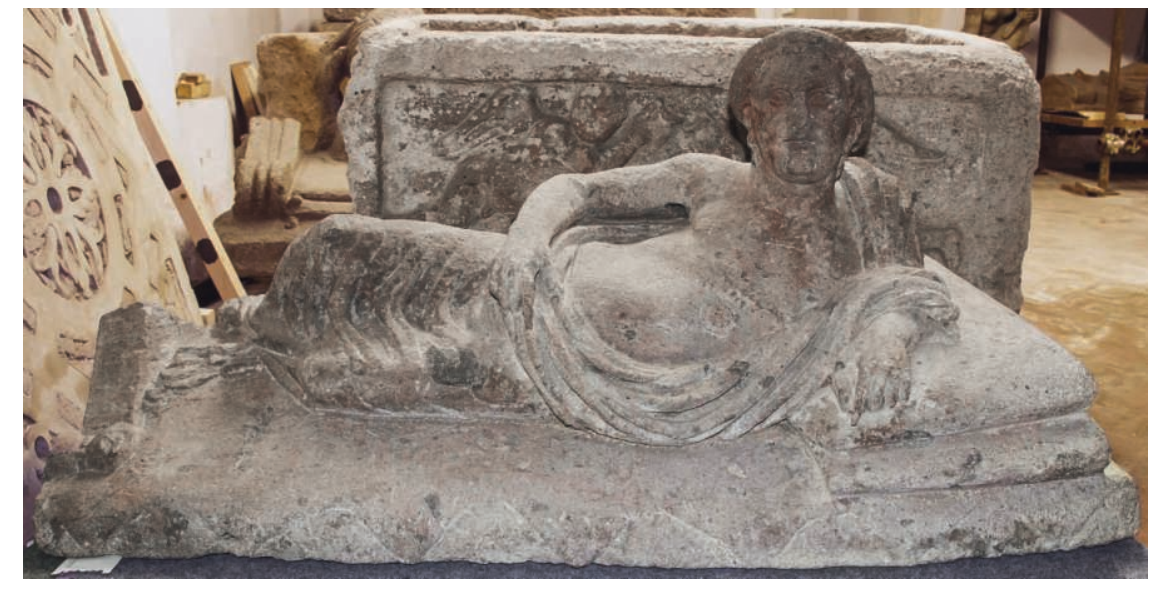

Fig. 4. Sarcophagus of a young boy, from Tuscania, Carcarello necropolis, Vipinana's tomb, first half of 3rd century B.C., nenfro stone $(65 \times 130 \times 60 \mathrm{~cm})$, Villa Corsini a Castello (inv. 74841). C ICVBC-CNR. 

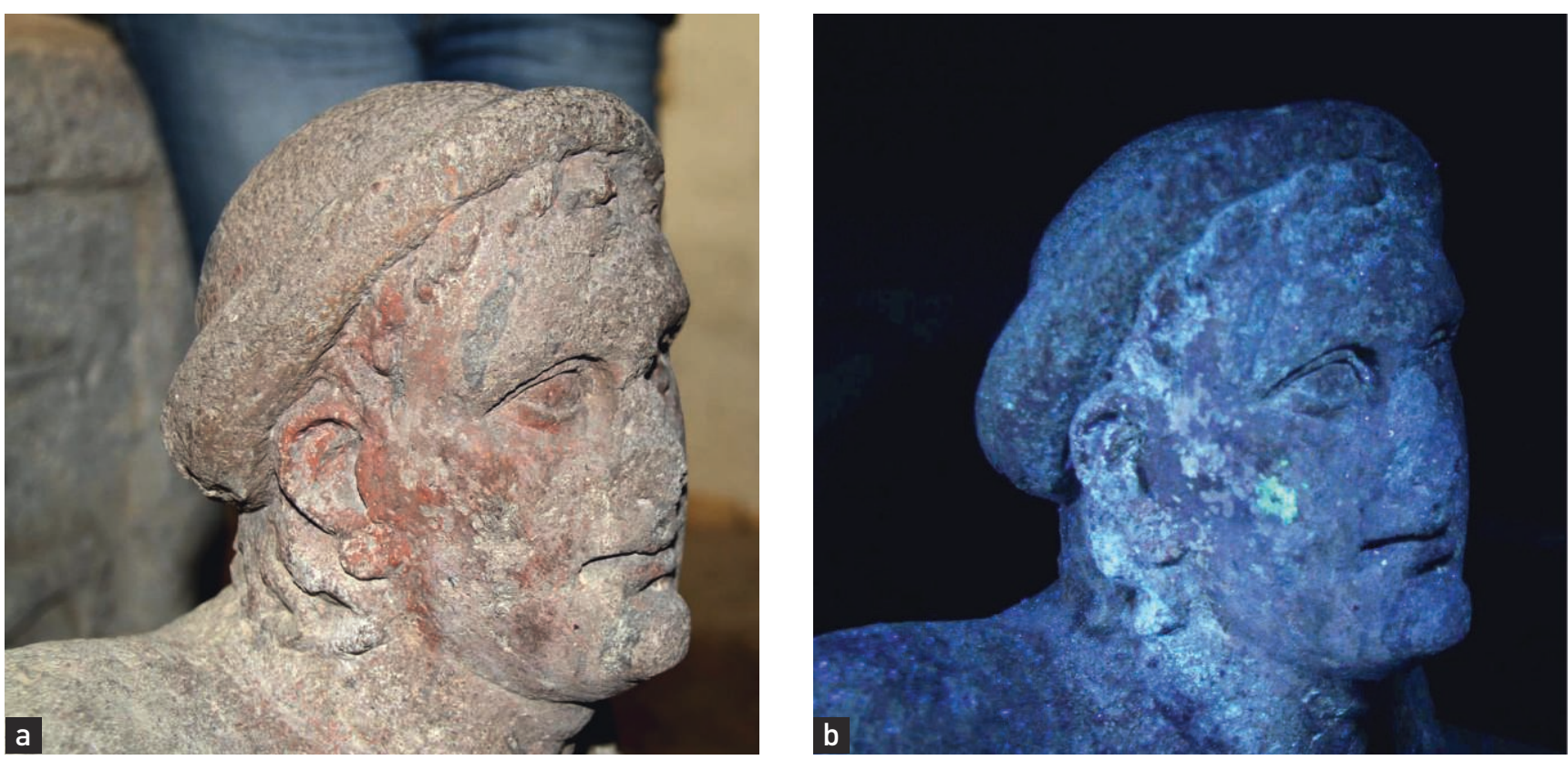

Fig. $5 a$ a-b. Detail of the visible (a) and UVf (b) images of the head of the young boy on the sarcophagus from Vipinana's tomb. ๑ ICVBC-CNR

On the sarcophagus, iron oxides were found in correspondence with the face (fig. 5 a), suggesting the use of an iron based pigment such as ochre to represent the skin. Observed under UV radiation, only the face shows a fluorescent area in correspondence with a lacuna in the red layer on the right cheek (fig. 5 b). The colour of the fluorescence suggests a deposit or stain of a modern material.

\section{Two female funerary hellenistic statues from Tuscania}

Two other monuments, almost unknown and recently published, were subjected to analysis. They are completely different from each other, but they are united by their uniqueness in Hellenistic Tuscania.

The first one is a female statue with a cloak, seated on a throne with a circular back (fig. 6). The sculpture is composed of two parts: a hollow base with waves and a rose-shaped decoration, and an anthropomorphic lid; the face is not original. It was part of the collection of the antique dealer Valeri and it was placed for many years on his drugstore terrace in Tuscania. In 1895, when Valeri died, it was purchased by the Museum thanks to Cerasa. Few details are known about its provenance, but it was found in the mid-18th century in a funerary structure, previously violated, in the Pian di Mola necropolis, together with Hellenistic vessels.

Due to its peculiar shape, we can hypothesize that it was an ash container. Similar objects are known in Chiusi and its territory, but so far it is unique in Tuscania funerary sculpture, considering that incineration was rare in a place where inhumation was significantly prevalent in family tombs. It is possible, but not verifiable without an epigraphic support, that its presence testifies the marriage of a member of Tuscania aristocracy with a woman coming from northern Etruria, who chose a burial ritual from her region of birth. Based on stylistic comparisons, the statue is considered as a local production and can be dated back to the second quarter of the 3rd century B.C. ${ }^{15}$

The FORS spectra acquired on the lips and on the neck revealed the presence of red iron based pigments (iron oxides, red ochre/hematite).

The measurement carried out in an area clearly affected by modern retouching on the face (fig. 6), showed the presence of iron oxides and hydroxides. A spectrum acquired on the blue area near the hair shows the possible presence of ultramarine, very likely not original. Even the blue of the eye would seem not original and was made with indigo.

The second unknown statue is a nenfro female headless torso, not allowing any possibility of dating the sculpture, with a slightly hollow base (fig. 7). Being a nenfro production, we think about a local manufacture. Found by Cerasa in Rosavecchia Necropolis in 1907, the same as Statlane's tombs, it was purchased by the Museum in the same year. Few information are available about all the other grave goods rescued but, reading the description, we can easily argue that it was a complex of the Hellenistic age. It is very difficult to hypothesize the nature of the sculpture. Its shape and relevancy to a funerary environment could suggest a burial function: it could have been an ash container as for the previous statue. The fact that no base was mentioned in the excavation journal could depend on the condition of the tomb; it could have been removed, or simply be part of the tomb structure: a hole carved in the tufa rock as it often happens for sarcophagi in coeval tombs ${ }^{16}$.

No traces of colours have been found on this female statue, except for a few traces of yellow ochre on the chest and 

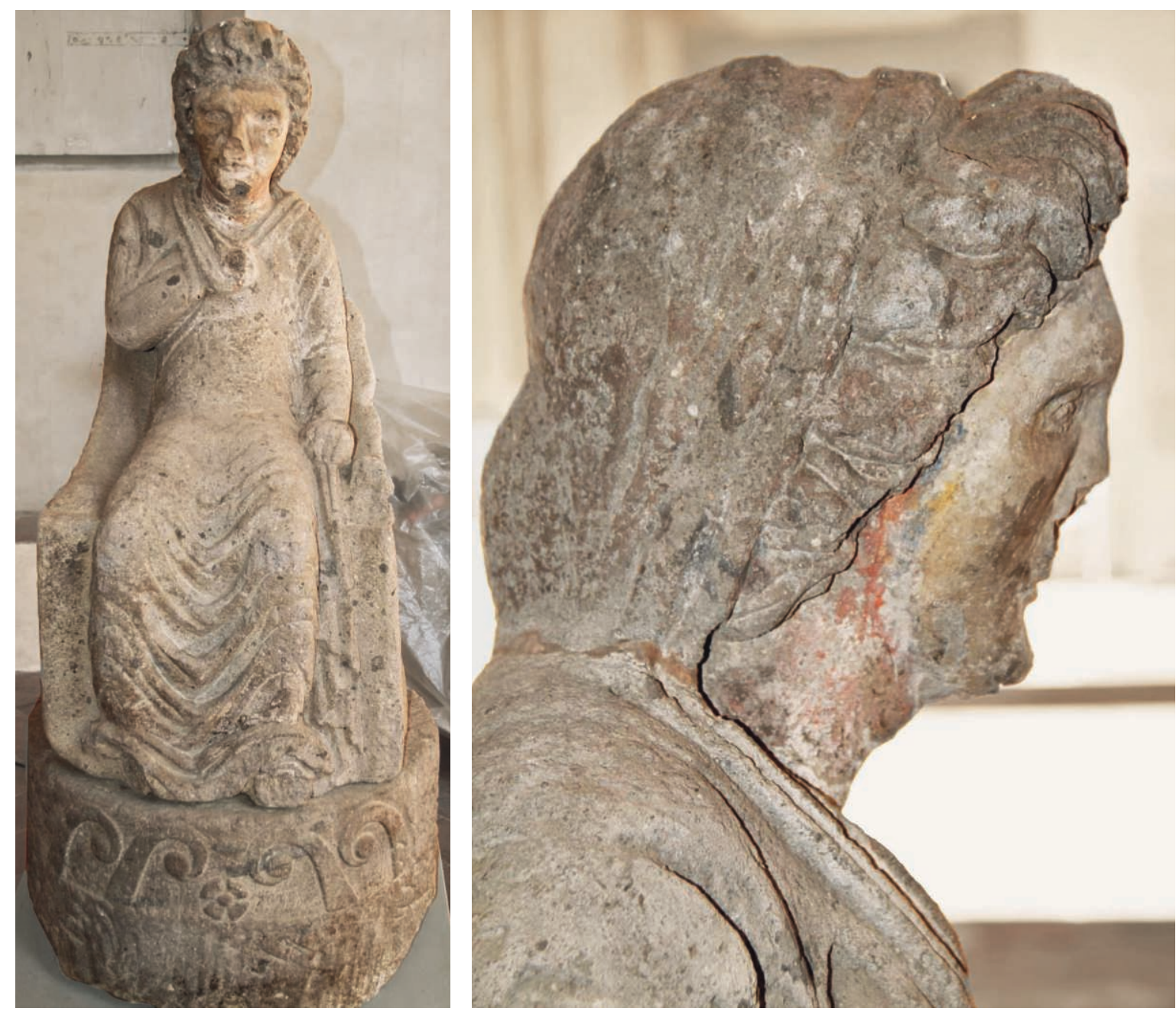

Fig. 6. Female statue with a cloak, seated on a throne (inv. 76194), from Tuscania. Pian di Mola necropolis, first half of 3 rd century B.C., nenfro stone ( 42 x $142 \times 70 \mathrm{~cm})$. ๑ ICVBC-CNR.
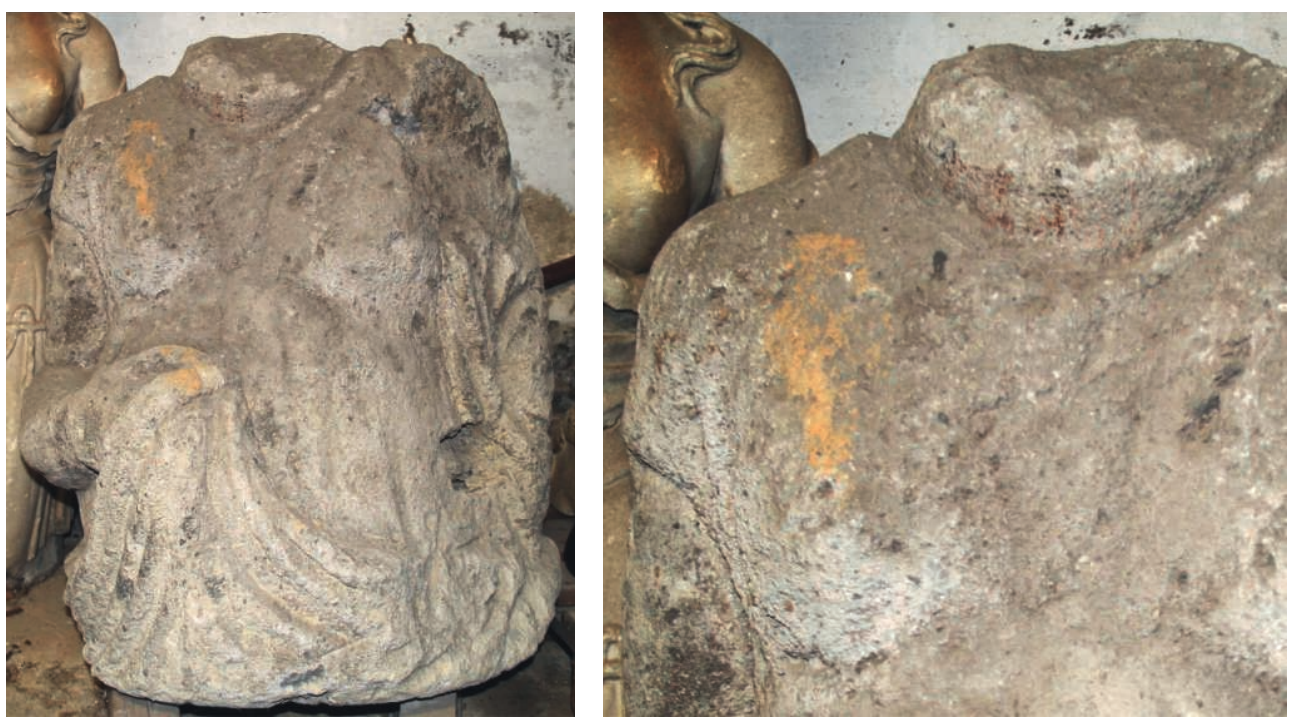

Fig. 7. Female torso, without head (without inventory number), Tuscania, Rosavecchia necropolis, Hellenistic period, nenfro stone (H. $25 \mathrm{~cm}$ ). @ ICVBC-CNR. 

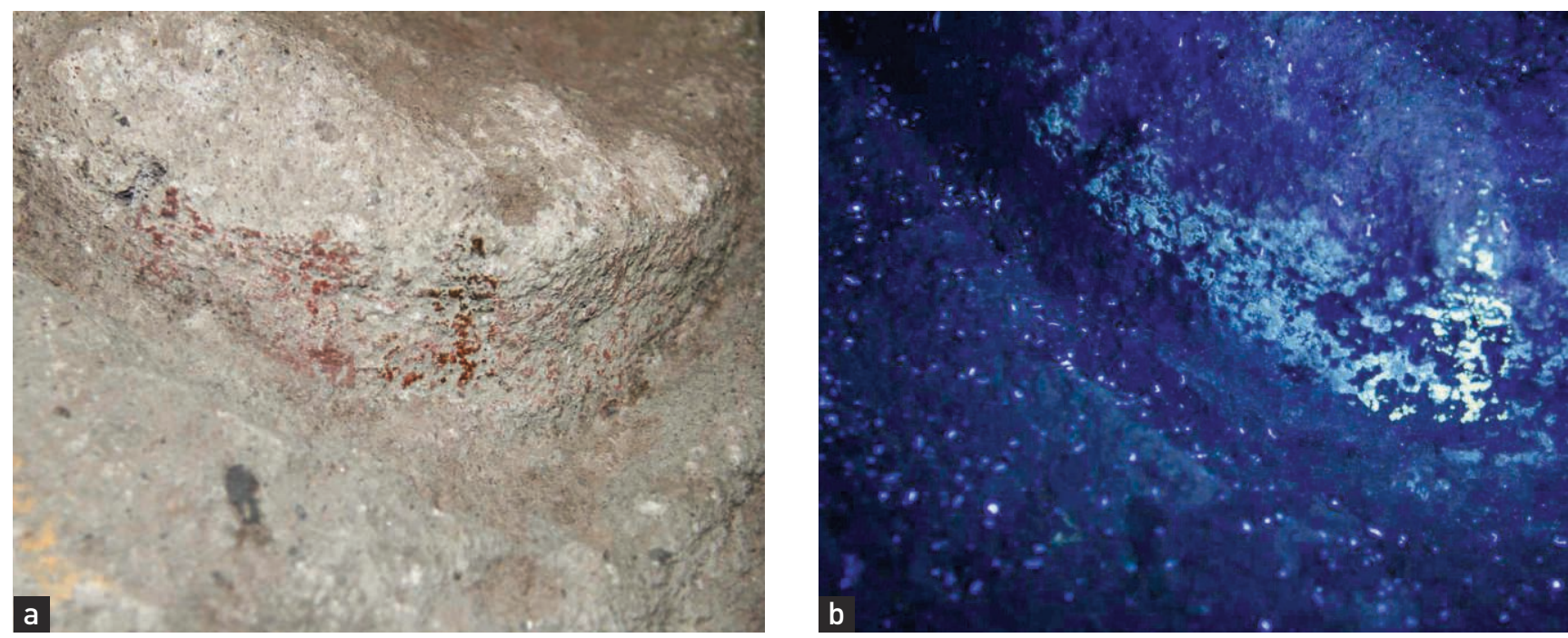

Fig. $8 a$-b. Detail of the neck of the female torso with traces of red ochre. Visible (a) and UVf (b) images. ( ICVBC-CNR.

red ochre on the neck (fig. 8 a-b). The ultraviolet fluorescence images show only a weak yellow emission that lies directly on the red trace. This fluorescence seems to be related to an altered organic material but it is not possible, by means of the techniques applied, to distinguish between a past restoration or the residues of an original material.

On each of these sculptures, several images were acquired through VIL technique, but unfortunately none of them revealed the presence of any trace of luminescence related to the Egyptian blue pigment.

\section{Conclusion}

Despite the damages due to the great flood of river Arno on November 4th, 1966, some traces of the polychromy of these nenfro sculpture were preserved ${ }^{17}$.

The colours of the sculptures, which are the object of this paper, are very faded and - except for the faint vestiges of Egyptian blue, highlighted by VIL and visible only with the microscope at high magnification, on the female lid (fig. 2) - , only some traces of red and yellow ochres were found. No traces of yellow, which was noticed at the time of the excavation, was found in the earrings of the woman on the female sarcophagus. The red traces that remained on the sculptures are mostly related to flesh tones ${ }^{18}$.

The durability of the colours on the surface surely is also affected by the type of stone used. Nenfro, indeed, is a volcanic tuff rock with a very compact, soft, porous and irregular structure ${ }^{19}$.

The results of this study add new data to the research about polychromy of Etruscan sculpture. The bibliography about this specific topic is growing ${ }^{20}$, but more examples of traces of colours can also be found in papers not directly related to the topic of ancient polychromy. For example, other stone sarcophagi with clear traces of polychromy are registered in the 1952 monograph by R. Herbig ${ }^{21}$ and in the 2001 paper by L. B. van der Meer ${ }^{22}$. Also among the Etruscan nenfro funerary lions, we have other examples of traces of colours easily recognizable by the naked eye and reported in the bibliography ${ }^{23}$.

Coming back to the case-study of Tuscania, more and more traces are now attested on another kind of finds from the necropolis: the terracotta sarcophagi - a topic of further research ${ }^{24}$. This last production started in the mid-3rd century B.C. and became predominant after a few decades, while the production of nenfro sarcophagi was declining and disappearing ${ }^{25}$. The comparison of polychrome choices between the production of nenfro and terracotta will be useful for a better understanding of the painted decorations of the graves in Tuscania.

\section{Experimental Appendix}

\section{Multispectral imaging}

For the UVf investigation, a Canon EOS 7D (18 Mpixel, CMOS sensor) was used, equipped with Canon EFS 18-135 mm f/3,5-5,6 IS lens \& B+W 486 UV/IR blocking, as filter for UV stray radiation and, as source, two flashes Quantum Qflash T5dR \& B+W UV black 403.

For the VIL investigation, a modified Canon EOS 400D (10Mpixel, CMOS sensor) was used, equipped with Canon EFS 18-135 mm f/3,5-5,6 IS lens \& 093 B+W IR filter and, as source, two flashes Quantum Qflash T5dR \& B+W 486 UV/IR blocking.

\section{Digital microscopy}

Digital images were acquired by a portable microscope Scalar DG-2A equipped with optical zoom 25-200x. Images were acquired at 25x magnification (investigated area $13 \times 8 \mathrm{~mm}^{2}$ ). 


\section{Non-invasive analyses ( $p$-XRF and FORS)}

p-XRF spectra were acquired through a Tracer III SD by Bruker with rhodium anode with the following working parameters: $40 \mathrm{kV}-12 \mu \mathrm{A}$ and 60 seconds. The FORS measurements were performed with an Ocean Optic (mod. HR2000) spectrophotometer equipped with optical fibres and a tungsten lamp as light source. A measurement head with illumination and signal collection at $0^{\circ} / 0^{\circ}$ allowed acquisition of reflectance spectra from an area of approximately $2 \mathrm{~mm}^{2}$ in the spectral range from $350 \mathrm{~nm}$ to $900 \mathrm{~nm}$.
Notes

1. The authors sincerely thank Dr. Mario Iozzo and Dr. Carlotta Cianferoni for allowing them to study the finds. Results of these research are published in Noferi et al., 2018, p. 43-50.

2. Liverani et al., 2018, p. 95 ss.

3. Shugar, Mass, 2013.

4. Bacci, 2000.

5. Noferi, 2012, p. 159 ss.

6 . For more details about this funerary complex, see: Noferi, 2012, p. 159 ss. and Noferi et al., 2018, p. 43 ss., with further bibliography.

7. Noferi et al., 2018.

8. Noferi, 2012, n. 4, p. 186 ss.; note 115 and fig. 12 .

9. Herbig, 1952, p. 29.

10. Emiliozzi, 1991, p. 939 ss.

11. Noferi, 2015, p. 233 ss., with further bibliography.

12. Noferi, 2012, n. 12, p. 195 ss.; note 164 and fig. 21 a-c.

13. Noferi, 2012, n. 12, p. 195 ss.; note 164 and fig. 21 a-c.

14. Colonna, 1978, J12, p. 107 and tav. XXVII a-b.

15. Noferi, 2016, p. 59 ss. and tav. XIX, with bibliography for comparisons.

16. Noferi, 2016, p. 64 ss. and tav. XX.

17. See also Noferi et al., 2018.

18. About colours and pigments used

for flesh tones in Etruscan art, see for example, recently: Barbieri, 2015, p. 4-5; for terracotta objects, see Brøns, Buccarella Hedegaard, Rasmussen, 2016, p. 203; Brøns, Buccarella Hedegaard, Sargent, 2016, p. 60-61.

19. Ciccioli et al., 2010.

20. For example, recently,

Großekathöfer, 2010; Barbieri, Giachi,

Pallecchi, 2013; Donati, 2014.

21. Herbig, 1952, p. 114-115.

22. Van der Meer, 2001.

23. Nenfro lion from Blera: "bruno il corpo; giallo - arancio la criniera; rosse le fauci; bianchi i denti" (Emiliozzi, 1991, p. 948).

24. Some preliminary results were shown in the poster session of the 9 th International Round Table on Polychromy in Ancient Sculpture and Architecture (London, British Museum, 9-10 November 2018): D. Magrini, G. Bartolozzi, S. Bracci, R. Iannaccone, E. Cantisani, C. Cianferoni, S. Lenzi, C. Noferi, Analysis of residual polychromy on a group of terracotta sarcophagi coming from Tuscania (Viterbo) stored in the National Archaeological Museum of Florence (MAF).

25. About the development of the production of terracotta sarcophagi and the historical reasons of this phenomenon, see in particular Gentili, 1994, p. 154 and p. 187-188.

\section{Bibliography}

Bacci M., 2000, "UV-VIS-NIR, FT-IR, FORS Spectroscopies", in E. Ciliberto, G. Spoto (eds.), Modern Analytical Methods in Art and Archaeology (Chemical Analysis Series, 155), New York, p. 321-361.

Barbieri G., 2015, "Il colore nelle architetture funerarie di Sovana. La Tomba dei Demoni Alati e altri monumenti policromi", Fasti On Line Documents and Research [online] 343, read 15 November 2018, http://www. fastionline.org/docs/FOLDERit-2015-343.pdf

Barbieri G., Giachi G., Pallecchi P., 2013, Polychrome Rock Architectures: problems of colour preservation in the Etruscan necropolis of Sovana (Science and Technology for Cultural Heritage. Papers 2), Fabrizio Serra Editore, Pisa/Roma.

Brøns C., Buccarella Hedegaard S., Rasmussen K. L., 2016, "The real thing? Polychromy research employed in authenticity studies of Etruscan pinakes in the Ny Carlsberg Glyptotek", Studi Etruschi 79, p. 195-223.

Brøns C., Buccarella Hedegaard S., Sargent M. L., 2016, "Painted faces: investigations of polychromy on Etruscan antefixes in the Ny Carlsberg Glyptotek", Etruscan Studies. Journal of the Etruscan Foundation 19 (1), p. 23-67.

Ciccioli P., Cattuto C., Plescia P., Valentini V., Negrotti R., 2010, "Geochemical and engineering geological properties of the volcanic tuffs used in the Etruscan tombs of Norchia (northern Latium, Italy) and a study of the factors responsible for their rapid surface and structural decay", Archaeometry 52, 2, p. 229-251.

Colonna G., 1978, “Archeologia dell'età romantica in Etruria: i Campanari di Toscanella e la tomba dei Vipinana”, Studi Etruschi 46, p. 81-117.

Donati F., 2014, "Linee programmatiche per il riconoscimento e lo studio della policromia sulle urne etrusche e i sarcophagi romani”, in P. Liverani, U. Santamaria (eds.), Diversamente bianco. La policromia della scultura romana, Quasar, Roma, p. 129-148.

Emiliozzi A., 1991, "Leoni funerari da Ferento”, Miscellanea Etrusca e Italica in onore di Massimo Pallottino, Archeologia Classica XLIII, p. 939-953.

Gentili M. D., 1994, I sarcofagi etruschi in terracotta di età recente, Giorgio Bretschneider Editore, Roma.

Großekathöfer J., 2010, "As the Moon is to the Sun? Current Research on Polychromy on Etruscan Sculpture", in
V. Brinkmann, O. Primavesi, M. Hollein (eds.), Circumlitio. The polychromy of antique and mediaeval sculpture, 10-12 December 2008, Liebieghaus Skulpturensammlung-Frankfurt am Main, Frankfurt am Main, p. 258-276.

Herbig R., 1952, Die jüngeretruskischen Steinsarkophage, Verlag Gebr. Mann, Berlin.

Liverani P., Bracci S., Iannaccone R., Lenzi S., Magrini D., Mazzei B., 2018, "Colours in the dark. New research into catacombs", in S. Bracci, G. Giachi, P. Liverani, P. Pallecchi, F. Paolucci (eds.), Polychromy in Ancient Sculpture and Architecture, Proceedings of the 7th Round Table on Polychromy in Ancient Sculpture and Architecture, 4-6 November 2015, Galleria degli Uffizi (Firenze), Sillabe, Livorno, p. $95-105$.

Noferi C., 2012, "Le Tombe della Gens Statlane nella necropoli di Tuscania", Annuario dell'Accademia Etrusca di Cortona XXXIII, p. 159-264.

Noferi C., 2015, "Il leone monumentale di Val Vidone al Museo Archeologico Nazionale di Firenze. Considerazioni sul contesto di provenienza", Accademia Toscana di Scienze e Lettere " $\mathrm{La}$ Colombaria". Atti e Memorie, vol. LXXIXLXXX, 2014-2015, p. 233-245.

Noferi C., 2016, "Monumenti funerari ellenistici a Tuscania. Considerazioni su due sculture del Museo Archeologico Nazionale di Firenze", Rivista di Archeologia 15, p. 59-67.

Noferi C., Bracci S., Iannaccone R., Lenzi S. Magrini D., 2018, "Consideration about polychromy on a group of Nenfro sarcophagi at the Archaeological Museum in Florence, from Gens Statlane tomb in Tuscania (Viterbo)", Polychromy in Ancient Sculpture and Architecture, Proceedings of the 7th Round Table on Polychromy in Ancient Sculpture and Architecture, 4-6 November 2015, Galleria degli Uffizi (Firenze), Sillabe, Livorno, p. 43-50.

Shugar A. N., Mass J. L., 2013, Handheld XRF for Art and Archaeology, Leuven University Press, Leuven.

van der Meer L. B., 2001, "Decorated Etruscan Stone Sarcophagi. A Chronological and Bibliographical Appendix to R. Herbig, Die jüngeretruskischen Steinsarkophage (Berlin 1952)", Bulletin antieke beschaving. Annual Papers on Classical Archaeology 76, p. $79-100$. 